Thirty-six forest authorities presented statements on Empire forests and the War. These were not merely of interest, but were particularly valuable as a record on such matters as : the areas of land under forest; total volume of standing timber and of increment; output of home-grown wood; imports and exports for pre-war years and for each war year ; the effect of war-time exploitation on forest capital and future increment (the latter more or less guesswork in most cases) ; and, lastly, the lessons to be learned from war-time experience-especially the often quite unnecessary and unjustifiable war-time extravagance. The data acquired have been analysed and summarized by the Central Statistical Office and printed as a publication entitled "Empire Forests and the War. A Digest of Statistics prepared by the Fifth British Empire Forestry Conference" (H.M. Stationery Office).

The subject of land-use came under the consideration of one of the sections of the Conference. In the Fourth Conference held in South Africa in 1935, under resolution No. 2 the Governments of the Empire were urged to maintain under vegetative cover catchment areas and other lands particularly liable to desiccation and erosion. This matter had first received public world-attention at the World Forestry Congress held in Rome in 1926 and was again brought up at the Second World Forestry Congress in Buda. pest in 1936. Those who have been studying this problem for many years know how little has been done as a result of the resolutions put forward on the subject at these Congresses.

One step, however, inaugurated in the United States, has made a start on promising lines, and that is the appointment of Soil Conservation Committees ; several similar bodies are also now working in several British Colonies and some of the Dominions. But this commencement, so far as it has gone, has been more or less confined to agriculture and its improvement in various ways; the real root of the matter, which rests in the maintenance of the forests of certain definite parts of the catchment areas of the world in the interests of agriculture, has not yet been really touched upon.

$|3| 6$

\section{COMMONWEALTH SCIENTIFIC AND INDUSTRIAL RESEARCH ORGANISATJON, AUSTRALIA}

$\mathrm{R}$ EFERENCE pâs made in Nature of April 30 , p. 671 , thending changes in the conduct of Governmant research in Australia. As from May 19, 1949, the-Australian Council for Scientific and Ind ytrial Research will be known as the Commonwe th Scientific and Industrial Research Organisa. tion. This announcement, was made on behalf of the Australian Government by the Hon. J. J. Dedman, Minister in Charge, who also announced the following appointments to the Executive of the Organisation : the chairman will be Dr. Ian Clunies Ross; the chief executive officer, Dr. F. W. G. White. Both were previously members of the Executive of the Commonwealth Council for Scientific and Industrial Research. They succeed Sir David Rivett and Dr. A. E. V. Richardson respectively. The new appointments will be for seven years. The third full-time executive member will be Dr. S. H. Bastow, formerly chief of the Division of Tribophysics, whose appointment will be for five years. The fourth member will be Mr. D. A. Mountjoy, whose three-year term expires next November. Mr. H. J. Goodes, assistant secretary, Commonwealth Treasury, has been appointed for three years to the fifth seat on the Executive.

Mr. Dedman said that he looked forward with confidence to the new Organisation continuing unbroken the long and honourable record of service which the Council had given to the Commonwealth. While the recent rapid expansion and widespread ramifications of the Council's work had led the Government to bring into being a new form of organisation more suited to present-day needs and responsibility, every care had been taken to preserve that freedom and initiative so essential for effective scientific work. All rights and privileges of officers of the old body would be safeguarded in the new, and Mr. Dedman said he had no doubt that the staff would find unimpaired the conditions of service and the high traditions built up over the past two decades.

Mr. Dedman paid a warm tribute to all those members of the former Council and its State committees whose disinterested service from its inception had contributed in marked degree to the success which had rewarded the Council's work. He had greatly appreciated the free and generous offer of the members of the Council to serve on the Advisory Council of the new Organisation, and, in the expectation that members of the State Committees would display a similar willingness, he would shortly extend an invitation, on behalf of the Government, to all of them to do so. It was particularly pleasing to him personally and to the Government that Sir David Rivett, while laying down the cares of his present office as chairman of the Council, had consented to ast as chairman of the new Advisory Council. On behalf of the Prime Minister and the Government of the Commonwealth, Mr. Dedman wished to place on record the substantial debt owed to Sir David Rivett and Dr. A. E. V. Richardson.

Sir David, as chief executive officer of the Council for Scientific and Industrial Research for just on twenty years and more recently as chairman, had become identified not only with the Council which, with its successor body, would always stand as a monument to his untiring care and wise direction, but also with Australian science in general. Sir David had seen the Council grow from small and uncertain beginnings to a great organisation of truly national proportions with an international reputation. On his retirement, Sir David would have the satisfaction of knowing that he carried with him the affection of his thousands of colleagues and the esteem of the whole community.

Dr. Richardson, first as member of the Executive committee of the Council, and later as deputy chief executive officer, and finally as chief executive officer, had brought to the Council an unrivalled knowledge of the problems of Australian agriculture, and a wide experience and sound judgment which had influenced all the Council's activities. He had played a major part in the development of the Council's work in the plant and animal industries than which none had yielded results of greater value to the Commonwealth. As dean of the Faculty of Agricul ture in the University of Melbourne, as first director and creator of the Waite Institute in South Australia. and as chief executive officer of the Council for Scientific and Industrial Research, Dr. Richardson's name would always be associated with the development of Australian agricultural science. 